AUTHOR:

Ngwabi Bhebe ${ }^{1}$,

AFFILIATION:

${ }^{1}$ Emeritus Professor,

Founding Vice Chancellor of the Midlands State University, Former Professor of History, University of Zimbabwe

EMAIL:

bheben@staff.msu.ac.zw

DOI: https://dx.doi.

org/10.18820/24150509/

SJCH45.v2.11

ISSN 0258-2422 (Print)

ISSN 2415-0509 (Online)

Southern Journal for

Contemporary History

2020 45(2):194-195

PUBLISHED:

30 December 2020

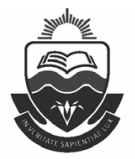

Published by the UFS

http://journals.ufs.ac.za/index.php/jch

(c) Creative Commons

With Attribution (CC-BY)

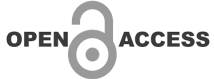

\section{OBITUARY FOR PROFESSOR CHENGETAI ZVOBGO}

Professor Chengetai Zvobgo will be remembered as a conscientious and hardworking scholar of history, who devoted himself to scrupulous research in archives to understand the social development of Africans in Zimbabwe in response to the western impact. He used the Christian missionary penetration of Zimbabwe at the beginning of the $20^{\text {th }}$ Century, starting with the Wesleyan Methodist Missionary Society, under the tutelage of the redoubtable Professor George Shepperson of Edinburgh University, as the launch pad of his lifetime intellectual pursuit. That journey soon broadened to cover all the missionary organisations that laboured in Zimbabwe and also embraced all their three ministries of teaching, healing as well as evangelisation.

Professor Zvobgo shows that the primary objective of the missionaries was to win African souls for Christ and to expand the Kingdom of God into the country. Western education and medical science were the twin tools the missionaries employed to demolish what they believed to be the superstitious basis of heathenism in order to prepare the mind for the Christian faith. Professor Zvobgo indeed demonstrates that missionary education, which in time received grudging support from the colonial state, was broad to include industrial training covering carpentry, building, agriculture and domestic science. All those trades contributed to transforming the material way of life of Africans. Thus, what was initially intended simply to be a basis for planting the Christian faith ended up producing Africans equipped with different skills, professions and other modern occupations. With time Professor 
Zvobgo matured into researching into Zimbabwe history in general, where he was able to show how the mission trained Africans developed to occupy the different sectors of modernising Zimbabwe society and economy.

At the same time as Professor Zvobgo was researching and writing history, he was also devoting himself to teaching and training students from undergraduate to PhDs. He was a renowned teacher, known for his witty humour and much loved by his students. 